\section{The Wayang Performance of Enthus Susmono: A Resistance of Tegal-Pesisiran Identity in Breaking the Tradition Hegemony}

\author{
Hariyanto ${ }^{1}$ \\ Ilmu Religi dan Budaya, Universitas Sanata Dharma Yogyakarta
}

DANCé

jurnal tari, teater, dan wayang volume 1 number 1, May 2018 page $1-12$

\begin{abstract}
This article aims to reveal and explain the process of cultural resistance appeared as a result of cultural violence conducted by authoritarian government regime in Indonesia. The standardization process of puppetry style, which was based on the tradition hegemony of Keraton Surakarta and Ngayogyakarta, in Enthus Susmono's view, was considered as being a political practice of cultural violence existed during the New Order era - a practice that seemed to eliminate minor puppetry traditions in the Javanese culture. It is in the framework of Titon's model that the appearance of a culture form may result from a historical memory that this article tries to explain the cultural resistance efforts by Susmono, which were represented in his performance of Wayang golek Gagrag Tegalan, in order to articulate the cultural identity of Tegal-Pesisiran.
\end{abstract}

Keywords: Enthus Susmono; wayang golek Tegal; wayang Pesisiran

\begin{abstract}
Abstrak
Wayang Gaya Enthus Susmono: Resistensi Identitas Tegal-Pesisiran dalam Mendobrak Hegemoni Tradisi. Tulisan ini ingin mengungkap serta menjelaskan proses resistensi kultural yang timbul akibat praktik kekerasan budaya oleh hegemoni rezim pemerintahan yang otoriter di Indonesia. Upaya standarisasi pedalangan yang berpijak pada hegemoni tradisi dua istana, yaitu Surakarta dan Ngayogyakarta, oleh Enthus Susmono dipandang sebagai praktik politik kekerasan budaya terjadi semasa Orde Baru, yang seolaholah menghilangkan berbagai tradisi kecil dunia pedalangan di Jawa. Melalui Pandangan Titon bahwa kemunculan sebuah bentuk kebudayaan yang didasari oleh memori kesejarahan, artikel ini menjelaskan mengenai resistensi kultural yang dilakukan Enthus Susmono, yakni melalui karyanya dalam pertunjukan Wayang Golek Gagrag Tegalan, untuk mengekspresikan dan mengartikulasikan identitas budaya Tegal-Pesisiran.
\end{abstract}

Kata kunci: Enthus Susmono; wayang golek Tegal; wayang Pesisiran

\section{Introduction}

During his life, Enthus Susmono inspired many people, such as common people and officials in Tegal, other Indonesian artistsespecially junior puppetry artist, that made them lost his figure. He was also well-known of being a controversial yet phenomenal puppetry artist who broke Indonesia puppetry with his works and performance. Susmono could not only perform using wayang kulit but also played wayang golek (rod puppets) well, either using Cepak or Sundanese style of wayang golek. However, he was once labeled as a puppeteer who "broke the standard style" by some more conservative puppeteers.

1 Correspondence: Ilmu Religi dan Budaya, Universitas Sanata Dharma Yogyakarta, Jln. Gejayan, Tromol Pos 29, Mrican, Yogyakarta. E-mail: abimanyuhariyanto@gmail.com. 
The label given by those conservatives, which called Susmono as uncommon, insane, and standard-rule breaker also attracted the attention of Sadiah Boonstra. Boonstra, in her disertation, Changing Wayang Scenes, called Susmono as a dalang who was good in reading situations, creative, trendy, and was also able to present refreshing discourse in performance arts as well as puppetry arts. He was also regarded as being aware and critical to either national or international socio-politic issues (Boonstra, 2014: 193-218). Susmono was also renowned as a puppeteer who was brave, confident, and straightforward in expressing his social criticism or political views to his audience. He chose to perform nonconventional wayang performance in order to break the standard inherited for years - the standard that he considered as being a limit and, thus, eliminated the freedom and independence in expressing one's artistry identity.

Susmono, during his performances, often performed an expressive style by presenting criticisms, irony, as well as humours mixed with expletives or vulgarism. Beforehand, he was also famous as a creative, innovative, funny, mischievous, critical, and even insane. Those images were revealed by several observers or researchers; for example, Kathryn Emerson (2016) -more famous as Kitsie Emersonwho mentioned him in her disertation, Transforming Wayang for Contemporary Audiences: Dramatic Expression in Purbo Asmoro's Style, 1989-2015; Jan Mrazek, in his book Phenomenology of A Puppet Theatre (2005), called his performance as "Pesta GadoGado" (Mixed Party) in the development of wayang kulitperformance arts, especially those relayed by an Indonesian private television channel -Indosiar. Susmono, indeed, often included music, campursari (modern Javanese music), humors, and other performances in his sections of Limbukan and Gara-gara.

However, one might realize thatSusmono's attitudes and choices in articulating his typical performances is not without any reasons. Was it because of the market demand - by offering an alternative wayang performance to certain consumers for popularity or for the sake of personal benefits? Did Susmono purposively create his performances on the basis of his own views? This paper tries to observe Susmono's performance style and career life from the perspective of cultural study.

In order to analyze the identity resistance of Tegal-Pesisiran performed by Susmono, two mutual theories were chosen. A theory proposed James C. Scott (2009) -as stated in Domination and the Arts of Resistence: Hidden Transcripts- is employed to observe the pattern of resistence interaction as a social movement; and another theory proposed by Jeff Todd Titon in his Worlds of Music (2009) is used as a Music-Culture Performance Model. The data of this research were taken from a number of Ki Enthus Susmono's wayang performances that had been uploaded to Youtube channel since the New Order era until the year of 2018.

The recorded shows being observed were: wayang kulit show aired by Indosiar in 1997, entitled with Sugriwa-Subali; wayang kulit show aired by Indosiar in 2001, of SugriwaSubali play; wayang kulit show aired by East Java TVRI station (no exact year, but there was an information that it was performed during the occurrence of lumpur Lapindo), with the story of Pandhawa Gugat; a show of wayang kulit with the play of Petruk Dadi Ratu; a wayang kulit show performed in the $3^{\text {rd }}$ International Puppets Festival in Denpasar, Bali, with the play of Dewa Ruci; a wayang kulit show performed routinely in Taman Budaya Jawa Tengah, dated 17 March 2011, using the play of Subali Lena; a wayang kulit show in Rembang, 2017, using the play of Pandhawa Layar; a wayang kulit show in Purwodadi, 2018, with the play of Banjaran Gathotkaca; the 2018 wayang santri using the play of Lupit Dadi Jaksa; the 2018 wayang santri using the play of Lupit Dadi Dhukun; a wayang santri performed in the event of Suran TegalrejoMagelang, 13 December 2012 using the play of Pengkhianatan Delilah; a wayang santri with the play of Anjala-Anjali; a wayang santri in the event of General Speech of Hari Santri PKB, 14 October 2015 in Jakarta, with the play of Lupit Nulung Putri; a show of wayang golek 
gagrag Tegalan performed in the closing event of The World Puppets Day in ISI Surakarta, with the play of Kembang Wijaya Kusuma; a show wayang golek gagrag Tegalan performed in the event of pesta sedekah laut (an offering ceremony to ocean) in Tegal Harbor, December 2017, with the play of Resi Adam Awal - Adam Akhir.

The aspects of observations include kinds of performances (wayang kulit-santri-golek tegalan); sources (Youtube, direct observation); period/year/events; play performed; performance structure; duration-play synopsis-plotting of scenes-accompanying music; language use; focused scene-focused dialogs or narrations-puppets-kelir and simpingan wayang-and, stage layout.

\section{Discussion}

The analysis of this paper was initiated based on two significant events related to Ki Enthus Susmono in the world of puppetry. On November 6, 2016, in the closing session of World Puppetry Day 2016 held by Indonesia Arts Institute Surakarta, there was a show by Susmono -a well-known dalang from Tegal, Central Java- who performed Wayang golek Gagrag Tegalan (WWGT-Wayang golek Tegalan Style). During the two-day event, audience showed great enthusiasm watching wayang performances. It was even greater when Susmono gave his performance to indicate that his name brought different attraction to the audience.

Enthus Susmono, in his speech, claimed that his WGGT show that night was performed publicly for the first time. He also mentioned that the WGGT show had been examined for his Honoris Causa Doctoral degree in Semarang State University. In that event, Susmono chose to perform Lakon Kembang Wijaya Kusuma play, a story of carangan play originated from local story, instead of the story taken from Mahabharata or Ramayana story.

The structure of the WGGT show performed by Susmono started by a karawitan music Talu Lompong Kèli, a typical music of Tegalan. It was then followed by a dance performed by a female dance similar to ronggeng, an energetic dance accompanied by dynamic music as the show went to the scene of Dhukuh Pakuan hermitage. The female dancer in the WGGT show was peculiarly different compared to what had been stated by Cahya (2014: 201) in his dissertation "Garap Pertunjukan Wayang Golek Sunda: Sajian Tjetjep Supriadi, Dede Amung Sutarya, dan Asep Sunandar Sunarya." Cahya also mentioned that in the wayang golek purwa Sunda show, after performing the dance of Gugunungan (Kayon, Javanese), it will then be followed by a dance (ibingan parekan) of Maktal Citrasena or Emban Geulis and Emban Kembu dolls. In addition, it could also be observed that the pattern of the dance performed in the WGGT differed from those of Sundanese emban wayang golek.

When the female dance finished, some characters appeared on the stage, Resi Sukmaraga and his son, Raden Cakradewa, accompanied by their loyal servants, Slentheng and Lupit. The characters of Slentheng and Lupit was morphologically similar to the character of Cepot Astrajingga - a character in the wayang golek purwa Sunda. Those two characters were originally created by Susmono as a transformation of Punakawan (servants) in Tegalese wayang kulit, named as Grubug - it has similar appearance to the character of Bagong or Bawor, as stated by Susmono in a book discussion event in November 2016. After the appearance of those four characters, the music dropped, then the puppeteer read janturan (narration to describe the scene) using Tegalan language. Based on the writer's observation, the manggala (opening) of janturan used by Susmono was quite identical with those used by other puppeteers of Banyumasan style.

The first scene in Dhukuh Pakuan hermitage told about the wary of Ayodya people who were suffering from various disasters and moral crimes. Resi Sukmaraga advised his son, Cakradewa, to faithfully pray to God, making some efforts for solving the problem of their country. Cakradewa, then, was commanded to find Kembang Wijaya 
flower that was believed to grow in Mentala Cave and was guarded by a spirit, named Siluman Buta Wadon.

The next scene narrated the existence of Siluman Buta Wadon and her guardians who guarded Kembang Wijaya Kusuma. The arrival of Cakradewa to their place triggered a fight won by Cakradewa. When Cakradewa successfully picked the flower, the Siluman Buta Wadon magically changed into a beautiful princess, Dewi Ambarbulan.

Apart from the structure of WGGT, Susmono used different kinds of puppets in the show. Among them were wayang golek Cepak puppets that develop in the coastal areas of northern Java, including Cirebon-Indramayu to Tegal - the puppet could be identified from its facial and head forms and its slight body; wayang golek purwa Sunda which could be morphologically identified by its facial form and carving, and its big body. The puppets of wayang golek Cepak were used mostly for simpingan. While for the purpose of sabet, Susmono used some puppets of wayang golek Cepak and some others from the puppets of wayang golek purwa Sunda.

Besides using different kinds of puppets, Susmono also demonstrated various puppet movements at that night. He adopted the movements of wayang golek Cepak, wayang golek Menak, and wayang golek purwa Sunda. The special movements of wayang golek Menak are ongklèk, ulap-ulap, seblak sampur, and tanjak (as being stated by Sukistono, 2013: 190). Wayang golek purwa Sunda movements are characterized by their specific movements as used in dance, such as gedig, keupat, galieur, and godeg (Cahya, 2014: 149).

The scenes used by Susmono on the WGGT show of Lakon Kembang Wijaya Kusuma could be considered to be mixed and adopted from wayang golek purwa Sunda scene plotting. The plot pattern of Sundanese wayang golek is commonly called as bedrip, as stated by Cahya (2014: 199-205) and Foley, in her dissertation "The Sundanese Wayang Golek: the Rod Puppet Theatre of West Java" (1979: 111).

Meanwhile, the language used in Susmono's puppet show for janturan- kandha-pocapan (the narration spoken by the puppeteer), suluk (songs and lyrics sung by the puppeteer) represented the language of TegalPesisiran. The language of Tegal-Pesisiran in the coastal areas of northern Java is widely known to have its distinctive features that are different from other languages and dialects used in Central Java. People usually mention it as panginyongan Tegal language or dialect (Susmono, 2016: i), or more commonly known as ngapak or Banyumasan dialect (as referring to the area of ex-Banyumas Residency which still speaks the language of Ngapak). However, as explained by Widyaningsih (2014), every dialect has its distinctive linguistic features.

Based on the observation during the show, the WGGT, which could be considered as a hybrid show, revealed some questions, such as the cultural identity form of the society in the coastal areas of northern Java, especially in Tegal (referred later as Tegal-Pesisiran) that was represented in the show of WGGT; whether the cultural identity of Tegal Pesisiran was formed as a result of the encounter of different cultures in the coastal areas in northern Java and the Sundanese indigenous culture that were mutually influencing and creating new culture form.

A day after the WGGT show, the writer attended an event, the Opening of Wayang Exhibition by Enthus Susmono - Enthusiasm, on November 9, 2016 in Katamsi Gallery of Indonesia Arts Institute Yogyakarta. The event also held book discussion of Susmono's books, who wrote and published two books at that time. The first book entitled with Wayang Gagrak Tegal (2016) tells about the description of Tegalese wayang that was historically explained using preceding literatures. Moreover, the second book, entitled with Pakeliran Wayang Gagrak Tegal, Jati Kusuma (2016), shares information about guidelines and procedures (caking pakeliran) to perform Wayang Gagrak Tegal of Jati Kusuma play, including its narration, suluk, or its traditional music arrangement.

Attended all those events about the works of Enthus Susmono, the writer found several interesting phenomena to be further analyzed. 
Besides the use of various puppets and puppet movements, Susmono also revealed some intriguing expressions in his book that explains the matter of wayang Gagrag Tegalan, its historical and political aspects related to its identity and existence. In the book, Susmono expressed his anxiety about the identities of Tegal people (Tegal-Pesisiran) which could be commonly recognized; one of them was the use of panginyongan dialect.

The so-called Tegal dialect is recognized by common societies more in its context as a humor, mockery, or even parody to arouse laughter; as what can be seen from the phenomena in the society where some Indonesian entertainers, like Cici Tegal, Parto Patrio, and several others gain their popularities and benefits from using the dialect in their jokes. The mockery was often followed by a stigma about Tegal-Pesisiran people, as experienced by Susmono who was often being reviled. He was regarded as being incompetent to perform wayang and lacked of well-established habitude, attitude, and ability to speak good Javanesse language compared to people from Surakarta and Yogyakarta, who are concidered better in every of those aspects.

In other words, the identity of TegalPesisiran could be considered as a marginal culture that might be resulted from public opinion that had been constructed in terms of standard Javanese cultures referring to two primary traditional kingdoms -Surakarta and Yogyakarta. Moreover, Susmono also expressed his suspicion about the possibility of how the Tegalese cultural identity had been politically put in dormant by the former ruler (Susmono, 2016: 18).

\section{General Review of Puppetry Style in Indonesia}

Wayang kulit, which is generally known to exist only in Surakarta and Yogyakarta, is also widespread in other areas than Java island, such as Sumatera, Kalimantan, and Sulawesi in various styles or gagrag. The term gagrag can be defined as ways that are commonly used (Poerwadarminta, 1939: 128). In this paper, the word gagrag is employed in referring to a Javanese common expression, kutha mawa tata desa mawa cara (either cities or countryside has its own rules and customs). Thus, the term gagrag could also be referred as a style or distinctness related to culture or local tradition of a particular place. According to Haryanto in his book, Pratiwimba Adiluhung, Sejarah dan Perkembangan Wayang (1988: 48-59), based on its narrative sources, wayang kulit in Indonesia can be classified into wayang kulit purwa with its narrative sources are from Mahabharata and Ramayana; wayang kulit Menak that gets its story from serat Menak; wayang kulit Sasak which is originated from the story of serta Menak and local stories of Sasak tribe; wayang purwa Bali, wayang Calonarang Bali; wayang Wahyu and wayang Warta which chronicle the stories of Old and New Testaments, including the death and ascension of Jesus Christ.

Wayang kulit (shadow puppets), based on its local characteristics or gagrag, can also be classified into several main traditions: gagrag Surakarta, gagrag Yogyakarta, gagrag Banyumasan, gagrag Kedhu, gagrag Jawa Timuran or more commonly known as wayang Cék-Dongan, gagrag Cerbon, and Dermayon. The gagrag Surakarta can be further classified into smaller traditions displaying distinctive local style, such as Klathénan, Sragénan, Wonogirén, Kasunanan (Keraton Surakarta), and Mangkunegaran (Pura Mangkunegara). Likewise, as stated by Kayam (2001: 28-58), gagrag Yogyakarta can also be categorized into several sub-gagrag: pathok negara (Kraton Kasultanan style), kidul negara (Bantul areas), kulon negara (Kulonprogo, Purworejo), lor negara (Sleman, Magelang), and étan negara (Gunungkidul areas). Gagrag Kedhu is also grouped into several local gagrag, such as Kedhu Wonosaban, Kedhu Temanggungan, and Kedhu Kebumenan (now grouped into Gagrag Banyumasan). Wayang kulit Jawa Timuran or Cék Dongan is categorized into several subgagrag in which each particular area has its own general and local characteristics that can be distinguished one another, such as from its keprak sound, gamelan music arrangement, 
suluk (songs sung by dalang), puppets, and cak pakeliran.

Similar to wayang kulit tradition, wayang golek (rod puppets) can also be grouped into several principal traditions, such as gagrag Sunda or Parahyangan, gagrag northern coastal areas including Cirebon, Indramayu, Brebes, Tegal, Pekalongan, and Batang with its distinctive wayang golek Cepak. In addition, there is also wayang golek Menak that is grouped into Menak gagrag Kebumen and Menak gagrag Yogyakarta. In Pasundan areas, wayang golek originates its stories from Mahabarata and Ramayana. Correspondingly, in the northern coastal areas of Java - Cirebon, Indramayu, Brebes, Tegal, and Pekalongan the stories are taken from serat Menak or babad stories which narrate myths or local stories (Susmono, 2016: 12). In conclusion, the wayang figures, ways of performing, language, music accompaniment, and other supporting means of wayang performance have their distinctive characteristics.

Concluding from various differences of gagrag, the term gagrag, then, can be seen as a cultural construction and entity possessed by a society to articulate its idealisms, life values, and social relations. Additionally, gagrag can also be regarded as a result from social interaction and receptions to express the existence and cultural identity of a society that engages multi-science experts to define it. For example, a process of interaction and reception that creates a gagrag has engaged some experts from fine arts (form shapes puppets morphology, patterns of sunggingan or colorings, pattern of wayang carvings), musicians (gamelan composer) who creates arrangements for particular gagrac, as well as the performers, or dalang, who act as narrators (can also be said as an intellectual actor who experts in the history of wayang, literature, and wayang mythology). A dalang is required to comprehend the knowledge to formulate all aspects related to a wayang performance procedure as a gagrag.

Gagrag, as an articulation of intellectual works and cultural identity of a society, also expresses various democratic discourses in the life of traditional societies. However, in its practice in Indonesia, during the New Order era, the variety of gagrag experienced cultural abuse, especially those that developed in the tradition excluded from two main Javanese traditions, Keraton Surakarta and Keraton Yogyakarta.

\section{The Idiomatic Cultural Legitimation of Keraton Surakarta-Yogyakarta}

In the collective memory of Indonesian people, either dalang or wayang has its own roles in the society's lives throughout Indonesian historical periods, as explained by Kayam in his work, Kelir Tanpa Batas (2001: 11-13). He summarized the opinion proposed by Groenendael (Dalang di Balik Wayang, 1987) which claimed that a dalang held a socio-religious position within a society, especially the Javanese societies. Dalang was considered for having a narrative skill as well as magical or supernatural power that he was able to be a medium of real life and supernatural world, the world of our ancestors and unearthly life. A dalang was also regarded as having a genealogical relation with the kings and their descendants, thus he gained special trust from the society where he lived because of his role as the nature guardian. Therefore, a dalang has been holding a dualism position of their roles and orientations, both to the rulers and to the people.

Based on the above explanation, it can be clearly seen that a dalang had a strategic role and how he interacted with the rulers in the past. In history, a dalang was close to the rulers, and even the ruler tended to dominate the dalang as his point person of his authority. And it was in this situation that there was a possibility of a cultural violence to the democratic life in Indonesia where the dalang and the society became the objects of the rulers' cultural violence.

Discussing about the authoritarian practice in Indonesia, Wijaya Herlambang (2013), in his composition -"Kekerasan Budaya Pasca 1965", provides an obvious illustration about the situation under the 
New Order regime. He claimed that the regime conducted a series of well-systematized and well-structuralized cultural violence in practicing its praxes to legitimate the anticommunism through Indonesian literature and film. The legitimation, furthermore, happened as well in many cultural aspects, such as performance arts, especially traditional arts and folk theaters.

The New Order rulers exploited culture as its instrument to practice the power hegemony by making cultural standardizations; one of them was the sacralization of the tradition symbols of two main kingdoms, Surakarta and Yogyakarta. Pemberton (2003: 13-39) also asserted that the New Order had revived and sacralized the symbols of Javanese culture (Surakarta Kingdom) as an ideal culture for the entire Javanese societies by means of its symbols, myths, and rites. The standardizations indicated how the New Order conducted authoritarian practice by administering cultural violence, which affected many aspects of the society's life, in order to maintain its authority.

The aspects affected by the New Order's cultural violence included the social paradigm, social relation, living pattern, and social discourse. The situation was a result from how the authority strictly controlled the society for giving a "secure" life for Indonesian people. As what has been stated by Shirashi (2009: 5 -9) in his work, Pahlawan-Pahlawan Belia, the Indonesian authority managed Indonesia as a family consisting of a father, a mother, and children. The regime authority acted as the father who controlled and superintended the children's behavior. The fiercely strict control made the citizens' lives similar to the situation of an interrogation room. Outside the room, everyone could freely move, but inside the glass wall, the father watched all the movements.

The strict control has triggered some reactions and resistance. The resistance appeared on the areas of a great distance from the center of the authority or from the culture centers being idealized by the authority. This article tries to reveal and explain the cultural resistance towards the cultural violence conducted by the New Order regime, by focusing on the phenomenon appeared in Tegal, Central Java, specifically its wayang performance, reflected in the works of Enthus Susmono who created his own identity separated from the Mataram culture.

The efforts of Indonesian authority to dominate traditional cultures in Indonesia was also reflected in the wayang performances. Pepadi (Persatuan Pedalangan Indonesia -Indonesian Puppeteers Association) and Senawangi (Sekretariat Nasional Pewayangan Indonesia -Indonesian National Wayang Secretariat) as the associations of Indonesian puppetry and puppeteers, during the New Order regimes had also been employed as a vehicle to strengthen the authority's hegemony praxes by making wayang performances and the puppeteers as the speakers of the government programs. Those can be seen in some articles published in Cempala magazine. In the magazine published by Pepadi from the first edition in 1966 to its last publication in 1999, in about 15 publications, some interesting phenomena could be observed. For example, the domination of Keraton Surakarta's cultural symbols could be identified from the appearances of the graphic pictures of wayang gagrag Surakarta; writers of gagrag Surakarta - either practitioners or experts of gagrag Surakarta; plays and plots of wayang referred to gagrag Surakarta; the existence of honorable discourse formulated from the kingdom's solo-centric cultural sources; and, explicit government programs. Thus, it can be concluded that during the regime of New Order, Indonesian puppetry and puppeteers had been the exploited objects of the authority in practicing their power hegemony. The contents of the magazine articles, discussions, illustrations- showed the standardization of Javanese wayang, especially in making the culture of Keraton Surakarta as the ideal standard of national culture.

Opinions voiced by people who lived in coastal areas or remote places about the puppeteers' gagrag had never been discussed by Pepadi or even the government. The 
discourses of worthy concept narrated in the magazine's articles tended to follow the rulers' urge for a requirement to preserve the pakem -a standard rule for puppeteer's performance in creating their works. The freedom to speak and democratic discourse formed throughout the past history on the variety of gagrag (styles) was being eliminated. The discourse was directed to the standard regarded as being ideal by the rulers, i.e. the cultures of two principal Javanese kingdoms, Surakarta and Yogyakarta.

Enthus Susmono appeared in the last edition of Cempala magazine, as well as a discussion about his interruption during the general meeting of Pekan Wayang (Indonesian Puppet Week) VII, on January 9, 1999 that represented the resistance and struggle of marginal group, the group of coastal people as voiced by Susmono. This struggle had found a new beginning to be articulated independently after the fall of New Order regime marked by former President Soeharto's resignation on May 22, 1998. Another interesting phenomenon was the picture of Enthus Susmono in that last edition wearing a shirt with a character of Lupit, a punakawan figure in Tegalan gagrag -an icon of Tegal-Pesisiran people. The prensence of Susmono along with the Lupit icon supported an assumption that the identity resistance of Tegal-Pesisiran voiced by Susmono started to gain its momentum.

\section{The Resistance of Cultural Identity of Tegal-Pesisiran by Enthus Susmono}

According to Scott (1990) in his book, Domination and the Arts of Resistance: Hidden Transcripts, a resistance appeared as a result from hegemony practice by a group of people or rulers, who conducted many dominating activities and legitimation to preserve their authority. Among those practices are repressive actions through exploitation. Either exploitation or domination practices create humiliation and submission, or even abused of the subordinate groups. The interaction patterns among subordinate groups that informally and subsequently maintained will create a resistance. Scott also claimed that the resistance interaction pattern is started by explaining the interaction of public transcript. In this pattern, the actor will cover or hide his motives. The subordinates will act as if they were obedient to the rulers, but they start to voice their needs or interest in different space; this will develop an interaction pattern of hidden transcript.

The interaction pattern of hidden transcript is represented through discourses including utterances, behaviors, and attitudes of the subordinate class which cannot be overtly expressed in public spaces. The activities within the interaction pattern may cover anonymous destruction or attack to places or facilities which become the symbol of the ruler's authority, though they keep it hidden without showing their struggle. Other activities may include language play, such as jokes or humor using codes known only by the subordinates. Others may struggle by spreading negative rumors or weaknesses of the rulers to destroy their image - their end result is to destroy the domination.

Susmono, as an Indonesian puppeteer, appeared to voice his people's aspiration to show their resistance to the ruler's domination -in this context, it was the legitimation of cultural dominating symbols of Keraton Surakarta and Yogyakarta), without doing repressive actions. Being dominated and abused, Susmono's social movements were committed as a respond to their history, showing the subordinate interaction pattern of the people in Tegal and Coastal areas. The next stage of interaction was building mass communication and power. In this stage, the social movement benefited from political maneuvers covered by art works or performances to gain recognition and to break the domination throughout the time.

The creative activities in art performances used local tradition symbols and idioms to show the resistance towards symbols and idioms of the dominance adopted by the ruler in toughening their hegemony over the citizens. In this very stage, certain new idioms 
were created by maintaining the spirit of the older idioms by giving quite similar meanings to them. In accordance with Scott's theory, the resistance efforts conducted by Susmono could be considered to pass several stages: stage of movement, stage of building collective awareness by creating communities (Sanggar Satria Laras), movements from subordinate class (the Coastal people); stage of creative process by accepting their historical experiences, creating new symbols and idioms, such as wayang puppets, music arrangements, gawangan kelir, the costume for dalang; stage of influencing the target groups (supportersactors-audiences of Surakarta-Yogyakarta cultures); and the stage of achievements.

Based on the writer's observation on the recordings of Susmono's performance while playing Subali-Sugriwa story in 1997 aired by Indosiar, Susmono was asked to perform in an event for the preparation of Indonesian General Election in Baki, Sukoharjo, Central Java. The event was attended by several government officials, and also Sinuwun Paku Buwono XII. In that performance, Susmono still used the pattern of Surakarta style -his music, puppets, stage layout, scene plotting, and procedure (cak pakeliran). Susmono also informed the government program and Dwifungsi ABRI (Bifunctions of Indonesian Army). At that time, Susmono was playing his role in the pattern of public transcript interaction as what is stated by Scott as commonly employed by political elite to build their image and to legitimate their power. Susmono acted like he was part of Surakarta style, nevertheless, he was trying to enter the hegemony group in order to prepare his next movements.

In that performance, Susmono not only presented humors using simple and assertive ngapak language, but also presented other idioms in form of a puppet character in one of the scenes. Thus, Susmono conducted the hidden transcript interaction pattern as what can be observed in his other performances. Susmono persisted building new idioms, such as using rai uwong puppets, planet puppets, teletubbies puppets, world famous people puppets, like Saddam Husein and George Bush, wayang golek of Slentheng Lupit that was transformed from the punakawan character in Tegalan style -the character of Grubug; using half-circle kelir or backdrop; using forms of wayang Kayon (gunungan kreasi); using modified Surakarta's srepegnem music arrangement, by inserting diatonic tones; involving shalawat (Islamic chants) into gamelan music arrangement of tradition's music pattern and structure; standing from his puppeteer's seat and then fighting with a giant puppet as tall as the backdrop. In additions, Susmono also inserted some swears or pisuhan during his performance. Pisuhan comes from the word "pisuh", which means swears or offensive words (Poerwadarminta, 1939: 454).

Tegal, as a city of harbor in the coastal areas in northern Java, after its fall during the Mataram legacy, was under the rule of VOC when it became a trade town which made it open to influences and cultural interactions from many other places. In its interactions, Tegal -at the boundary of Cirebon and Western Java- became a melting point of coastal and rural cultural traditions. Thus, it was possible that the process was followed by cross-cultural process among the cultures of Sundanese, Cirebon, Javanese, Chinese, and many others. Based on this assumption, in order to analyze the identity of Tegal-Pesisiran in the show of WGGT, we could use the claim of Titon (2009), in his book Worlds of Music: An Introduction to the Music of the World's, about the model of cultural music by stating the interaction pattern as follows:

\begin{tabular}{|c|c|c|c|}
\hline Affect & Performance & Community & $\begin{array}{c}\text { Memory/ } \\
\text { History }\end{array}$ \\
\hline
\end{tabular}

According to Titon (2009), the phenomenon of music culture is highly related to memory and historical matters. Meanwhile, affect is a musical nuance represented in a music work, thus, Titon claimed that music was born as a result from history and its society as its supporters, as the society itself was borne by its historical experiences. Therefore, Titon wrote a new scheme in the relation of performance arts: 


\begin{tabular}{|c|c|c|c|}
\hline Music & Performers & Audience & $\begin{array}{c}\text { Time and } \\
\text { Space }\end{array}$ \\
\hline
\end{tabular}

Referring to Titon's opinion, in this article, the elements of performing arts are transformed into the relation among:

\begin{tabular}{|c|c|c|c|}
\hline $\begin{array}{c}\text { WGTT } \\
\text { (the Identity } \\
\text { of Tegal- } \\
\text { Pesisiran) }\end{array}$ & $\begin{array}{c}\text { Performers } \\
\text { Susmono }\end{array}$ & Audience & $\begin{array}{c}\text { Time and } \\
\text { Space }\end{array}$ \\
\hline
\end{tabular}

From both relations, it can be concluded that WGGT which represented the identity of Tegal-Pesisiran was performed by $\mathrm{Ki}$ Enthus Susmono as the puppeteer. In the first scheme, the performance showed an interaction between memory and history being presented by the audience's support. Meanwhile, the audience itself borne by its history and its interaction with its history. The Affect showed the identity formed as a result from their reception of the social phenomena and history sentiment, as seen in the use of the puppets, the puppets movement pattern, the language, the music accompaniment, and the musical instruments used. Therefore, it could be clearly seen that the process of social movement conducted by Ki Enthus Susmono showed a resistance against the domination of the cultures of Keraton Surakarta and Yogyakarta legitimized by the New Order rulers during their authority.

\section{Conclussion}

Reading Susmono's opinion on his suspicion that the identity of Tegal-Pesisiran possibly was made dormant politically by Indonesian rulers, especially as what was reflected in the wayang performances, it is interesting to look into the background of Susmono's career in the puppetry arts. Based on the observations on the recordings of Susmono's performances in the periods of the New Order era, post-reformation, to the year of 2017, there were some significant differences and movements. In the New Order era, Susmono tended to perform using gagrag Surakarta; whereas, after the reformation era,
Susmono performed more freely exploring mixed puppetry styles by including several oher sub-styles, such as gagrak Yogyakarta, Banyumasan, Pesisiran, and Jawa-Timuran (Cek-Dongan). It was in the later period that Susmono created many creative works puppets, music accompaniment sheets, and performance concept - a concept referred as "standard breaking" by the conservatives.

The performance styles as referred by "standard breaking" could also be observed through his performance that included elements of gambus (a six-stringed Arabic musical instrument) music from Middle-East, the use of song lyrics taken from shalawat (Islamic chants), and consistently mixed language. Susmono was also consistent eschewing the use of Javanese puppetry language in his performances, which he considered too archaic. Instead, he used a combination of different languages, such panginyongan, Sundanese, ngoko Javanese (the lowest Javanese language level) languages; pisuhan (Javanese expletives, such as bajingan, lonthé, jancuk, and some others); and Indonesian language for expressing his social or political view. Therefore, it appeared that Susmono's performance was a part of resistance effort against the two dominating cultures from two kingdoms: Keraton Kasunanan Surakarta and Keraton Kasultanan Yogyakarta -the cultures appointed as the ideal standard of Javanese culture.

The practice of articulation as a resistance effort conducted by Susmono through his WGGT performance found its political momentum in defining the identity of TegalPesisiran. His position as a Regent and his Honoris Causa Doctoral degree from Semarang State University in the year of 2016 could be regarded as a symbol of the recognition and support from the society, especially the coastal society, towards his resistance effort. His effort to voice the identity of Tegal-Pesisiran society in his wayang performances, especially the WGGT, was regarded as being successful in forming it as a competitor of the dominating cultures (the cultures of Keraton Surakarta and Yogyakarta). The identity articulated in 
Susmono's performance that covered stage layout, puppets, music accompaniment, stage acts, plays, and fashion style was imitated and adopted by young puppeteers -either those from Surakarta style or those from Yogyakarta style, as well as puppeteers from Pesisir Pantura, such as from Indramayu, Brebes, Pemalang, to puppeteers of wayang golek purwa West Java.

\section{References}

Cahya. 2014. “Garap Pertunjukan Wayang Golek Sunda: Sajian Tjetjep Supriadi, Dede Amung Sutarya, dan Asep Sunandar Sunarya”. Dissertasion. Yogyakarta: Performing Arts and Fine Arts Study, Gadjah Mada University Yogyakarta.

Emerson, Kathryn. 2016. "Transforming Wayang for Contemporary Audiences: Dramatic Expression in Purbo Asmoro's Style 1989-2015". Dissertation. Leiden: Universiteit Leiden.

Foley, Kathy. 1979. "The Sundanese Wayang Golek: The Rod Puppet Theatre of West Java". Dissertation. Hawaii: University of Hawaii.

Groenendael, Victoria M.C. 1987. Dalang di Balik Wayang. Jakarta: Pustaka Utama Grafiti.

Haryanto S. 1988. Pratiwimba Adiluhung, Sejarah dan Perkembangan Wayang. Jakarta: Djambatan.

Herlambang, Wijaya. 2013. Kekerasan Budaya Pasca 1965: Bagaimana Orde Baru Melegitimasi Anti-Komunisme Melalui Sastra dan Film. Serpong: Marjin Kiri.

Kayam, Umar. 2001. Kelir Tanpa Batas. Yogyakarta: Gama Media.

Mrazek, Jan. 2005. Phenomenology of A Puppet Theatre: Contemplations on the Art of Javanese Wayang Kulit. Leiden: KITLV Press.

Pemberton, John. 2003. "Jawa" on The Subject of "Java". Yogyakarta: Mata Bangsa.

Poerwadarminta, WJS. 1939. Baoesastra Djawa. Batavia: Percetakan J.B. Wolters. Saukko, Paula. 2003. Doing Research in Cultural Studies. New Delhi: Sage Publications
India.

Sasaki Shiraishi, Saya. 2009. PahlawanPahlawan Belia. Jakarta: Nalar.

Scott, James C. 1990. Domination and the Arts of Resistance: Hidden Transcripts. London: Yale University Press.

Senawangi. 1999. Majalah Cempala, Jagad Pedalangan dan Pewayangan (Kumpulan Edisi Lengkap). Jakarta: Studio Delapanpuluh.

Sukistono, Dewanto. 2013. "Wayang Golek Menak Yogyakarta, Bentuk dan Struktur Pertunjukannya". Dissertation. Yogyakarta: Performing Arts and Fine Arts Study, Gadjah Mada University Yogyakarta.

Susmono, Enthus. 2016. Pakeliran Wayang Gagrak Tegal: Jati Kusuma. Prambanan: Rumah Empu.

Susmono, Enthus. 2016. Wayang Gagrak Tegal. Prambanan: Rumah Empu.

Titon, Jeff Todd. 2009. Worlds of Music: An Introduction to the Music of the World's Peoples. Boston: Cengage Lerning.

Widyaningsih, Rindha. 2014. "Bahasa Ngapak dan Mentalitas Orang Banyumas: Tinjauan dari Perspektif Filsafat Bahasa Hans-Georg Gadamer" in the Journal of Ultima Humaniora. September 2014.

\section{Recorded Performances}

Wayang Kulit (Leather Puppet Shadow) show aired by Indosiar in 1997, playing the story of Sugriwa-Subali. Downloaded from Youtube: 10 April 2018.

Wayang Kulit show aired by Indosiar in 2001, playing the story of Sugriwa-Subali. Downloaded from Youtube: 10 April 2018.

Wayang Kulit aired in TVRI East Java (no exact years, but there is an information that it was performed at the same time of the incident of Lumpur Lapindo), playing the story of Pandhawa Gugat. Downloaded from Youtube: 10 April 2018.

Wayang Kulit show with the story of Begawan Dawala. Downloaded from Youtube: 10 April 2018.

Wayang Kulit show in the event of Puppet 
Festival 2009, Denpasar Bali, playing the story of Dewa Ruci. Downloaded from Youtube: 10 April 2018.

Wayang Kulit routinely performed in Taman Budaya Central Java, 2015, playing the story of Subali Lena. Personal Recording.

Wayang Kulit in Rembang performed in 2017, playing the story of Pandhawa Layar. Downloaded from Youtube: 10 April 2018.

Wayang Kulit show in Purwodadi performed in 2018, playing the story of Banjaran Gathotkaca. Downloaded from Youtube: 10 April 2018.

Wayang Santri show playing the story of Lupit Dadi Jaksa. Downloaded from Youtube: 10 April 2018.

Wayang Santri show playing the story of Lupit Dadi Dhukun. Live Performance in Jatinegara, Tegal Regency in March 2018.

Wayang Santri show in Magelang in the year of 2015 playing the story of Samson Delilah. Downloaded from Youtube: 10 April 2018.

Wayang Santri show with the story of AnjalaAnjali. Downloaded from Youtube: 10 April 2018.

Wayang Santri show in the event of "Hari Lahir PKB" playing the story of Lupit Nulung Putri. Downloaded from Youtube: 10 April 2018.

Wayang Golek Gagrag Tegalan in the closing of World Puppets Day 2016 in ISI Surakarta, with the story of Kembang Wijaya Kesuma. Downloaded from Youtube: 10 April 2018.

Wayang Golek Gagrag Tegalan in the event of pesta sedekah laut Pelabuhan Tegal, in Desember 2017, playing the story of Resi Adam Awal-Adam Akhir. Downloaded from Youtube: 10 April 2018. 